Review Article

\title{
Meaningful Work and COVID-19: A Way Forward through LDW Model
}

\author{
Umair Ahmed1,* and Abdussalaam Iyanda Ismail ${ }^{2}$ \\ ${ }^{1}$ Arab Open University, Bahrain \\ 2University of Fujairah, U.A.E \\ umairahm@gmail.com; iyandaismail@yahoo.com \\ ${ }^{*}$ Correspondence: umairahm@gmail.com
}

\begin{abstract}
Received: $8^{\text {th }}$ August 2020; Accepted: $13^{\text {th }}$ October 2020; Published: $1^{\text {st }}$ November 2020
Abstract: The authors in the current paper objected to presenting a simple and actionable model for businesses to respond to the growing concern of employees` lost meaningfulness during the COVID-19. The study presents the LDW model, referring to leadership, employee development, and work-life-balance as core areas of focus for management and organizational authorities. The model is presented to help employees build a sense of meaning, purpose in their work, understand the significance of their contribution and individual value that appears to vanish due to uncertainties faced by every single business worldwide. The paper also discusses the importance of employees` sensing the work as meaningful and how it serves organizations in achieving their goals and objectives. In addition, the authors have also detailed concerning the need for responding to this issue and how it can be helpful in robust consequences for businesses, particularly during COVID-19. The LDW model not only offers the basis for addressing and responding towards the concept of meaningful work but is a route forward to countering any crisis affecting employees` sense of well-being, connectivity and contribution with the work.
\end{abstract}

Keyword: Meaningful work; Covid-19; Pandemic; LDW model; Well-being

\section{Introduction}

COVID-19 outbreak described as feverish respiratory disease (Loffredo et al., 2020) brought massive changes to nearly everything in the global marketplace. Employees and organizations have been going through several challenges and trying hard to overcome in the best possible manner. However, most of them appear to be struggling to maintain sales and revenues, resulting in job cuts for many and increased workload, reward cuts, work-life disbalance, pressure from supervisors and leaders, and increased demands for the rest. According to Fairlie (2011), intrinsic and extrinsic rewards, freedom at work, supportive leadership and supervision, healthy colleagueship, appreciating and recognizing supervision, organizational support in general work matters, and balance in work and life make the work meaningful for employees. In comparison, in the current situation when the rewards are reduced, leadership is not very cooperative, supervisory and colleague relationships are not very encouraging, organizational support is weak, and no balance in work and life, it would potentially affect the meaningfulness of the work. The paper indicates an important cognitive aspect affected by the recent COVID-19 Pandemic, the meaningfulness of work. The authors in the present study object to discuss the concept of meaningful work and its prominence for enterprises to get the work, efforts, and contribution from their employees that they need the most during the critical time. The authors have endeavoured to forward suggestions for

Umair Ahmed and Abdussalaam Iyanda Ismail, "Meaningful Work and COVID-19: A Way Forward through LDW Model”, $\underline{\text { Annals }}$ of Contemporary Developments in Management \& HR (ACDMHR), Print ISSN: 2632-7686, Online ISSN: 2632-7694, pp. 27-32, Vol. 2, No. 4, $1^{\text {st }}$ November 2020, Published by International Association of Educators and Researchers (IAER), DOI: 10.33166/ACDMHR.2020.04.004, Available: http://acdmhr.theiaer.org/archive/v2/v2n4/p4.html. 
organizations to consider as a viable plan to avoid employees viewing their work as less meaningful to ensure they can serve and support the business, today and tomorrow.

\section{COVID-19 Outbreak}

COVID-19 has not left any business or life sector unaffected (Darwish et al., 2020). Since its discovery in November 2019 in China, COVID-19 has completely altered how the world used to operate. Though initially, some thought it might not spread out of China; however, within a few months, more than half of the world ended up getting infected with it (Smith et al., 2020). This flu-based viral infection made people and businesses cautious about social interactions, bringing massive effects to businesses globally (Darwish et al., 2020). The conventional business processes have transformed, requiring employees to exert more effort, apply different techniques, and work under a lot of physical and mental pressure (Mo et al., 2020). Taken together, COVID-19 has altered the face of business and work life.

\subsection{Meaningful work}

Meaningful, meaningfulness and meaningful work are the terms interchangeably used for what Hackman and Oldham (1976) referred to as a job being considered as valuable, significant, and contributory by the individual. Typically, it is the individual appraisal of the job regarding its importance, significance, and contribution (Rosso et al., 2010). Individuals at work experience work as meaningful when they view their work being termed notable and supportive of the organization's goals and achievements (Ahmed et al., 2016). Meaningful work is a vital job resource and characteristic (Ahmed et al., 2019) and can predict important employee outcomes.

\subsection{Importance of Meaningful work:}

Meaningful work is the significance of work personally perceived by the individual. Studies have linked meaningful work with several elements and outcomes. For example, meaningful work can boost spirituality at work since it brings inner joy and content (Fairlie, 2011). Meaningful work also is coupled with social well-being as individuals experience more connectivity with all aspects of the work, including other involved individuals (Lysova et al., 2019). Employees who see work as meaningful express a greater level of meaning in everything from career to life and contribution to the world around them (Steger et al., 2012). In comparison, meaningless work is associated with work detachment and boredom (May et al., 2004). A recent meta-analysis underlined a strong association of meaningful work in cultivating employee engagement, commitment, job satisfaction, life satisfaction, life meaning, and general health (Allan et al., 2019). The results of this meta-analysis prove the strategic implications of meaningful work for businesses in the ongoing COVID-19 Pandemic.

\subsection{Notable Consequences of Meaningful Work:}

Dozens of studies are available, highlighting the role and contribution of meaningful work. Through a critical review of the literature, we underline a few that have the most significant results. Therein, some of the most promising contributions of meaningful work include employee engagement or work engagement. Engagement is a psychological state of mind of employees that ignites them to work with a higher level of commitment and vigour in work (Schaufeli et al., 2002). Research by prominent scholars has concluded the significance of meaningful work in predicting engagement in employees. Fairlie (2011) confirmed the importance of employee engagement with work engagement suggesting that employees who feel that they have an important role to play in the organization through their job role, it brings more enthusiasm, motivation, and energy in them; in other words, showing engagement. Besides, meaningful 
work has much importance when it comes to employees` mental health, as per the meta-analysis of Allan et al. (2019).

The findings also suggest that employees need to develop a sense of purpose, reason, and meaning with the work to remain happy and content with the work, which boosts mental well-being at work. Accordingly, a study by Geldenhuys et al. (2014) indicated a momentous role of meaningful work towards work engagement and organizational commitment. The study asserts that employees viewing their work being significant, having value towards the broader goals of the business, and being able to make sense of the work that they do for themselves can help them not only give the best in their work (engagement) but also brings out devotion and loyalty to the business (commitment).

\subsection{Rethinking the Workplaces through LDW Model}

The current paper presents the LDW model to underline three essential domains that every organization can conveniently work to respond to this issue of meaningful work. Herein, we suggest that Leadership, Development, and Work-life-balance are the core entities that can be taken into consideration. The aim of the LDW model is to offer areas of focus that every organization can look into without spending much of the scarce resources of any type. Undeniably, there could be many ways and factors through which organizations can help improve work meaningfulness, however, keeping in view the tough and financially challenging business circumstances the organizations globally are facing due to COVID-19, we believe that the LDW model is highly efficient and friendly in implementation. Figure 1 can be seen to obtain further information on the LDW model, which is as follows:

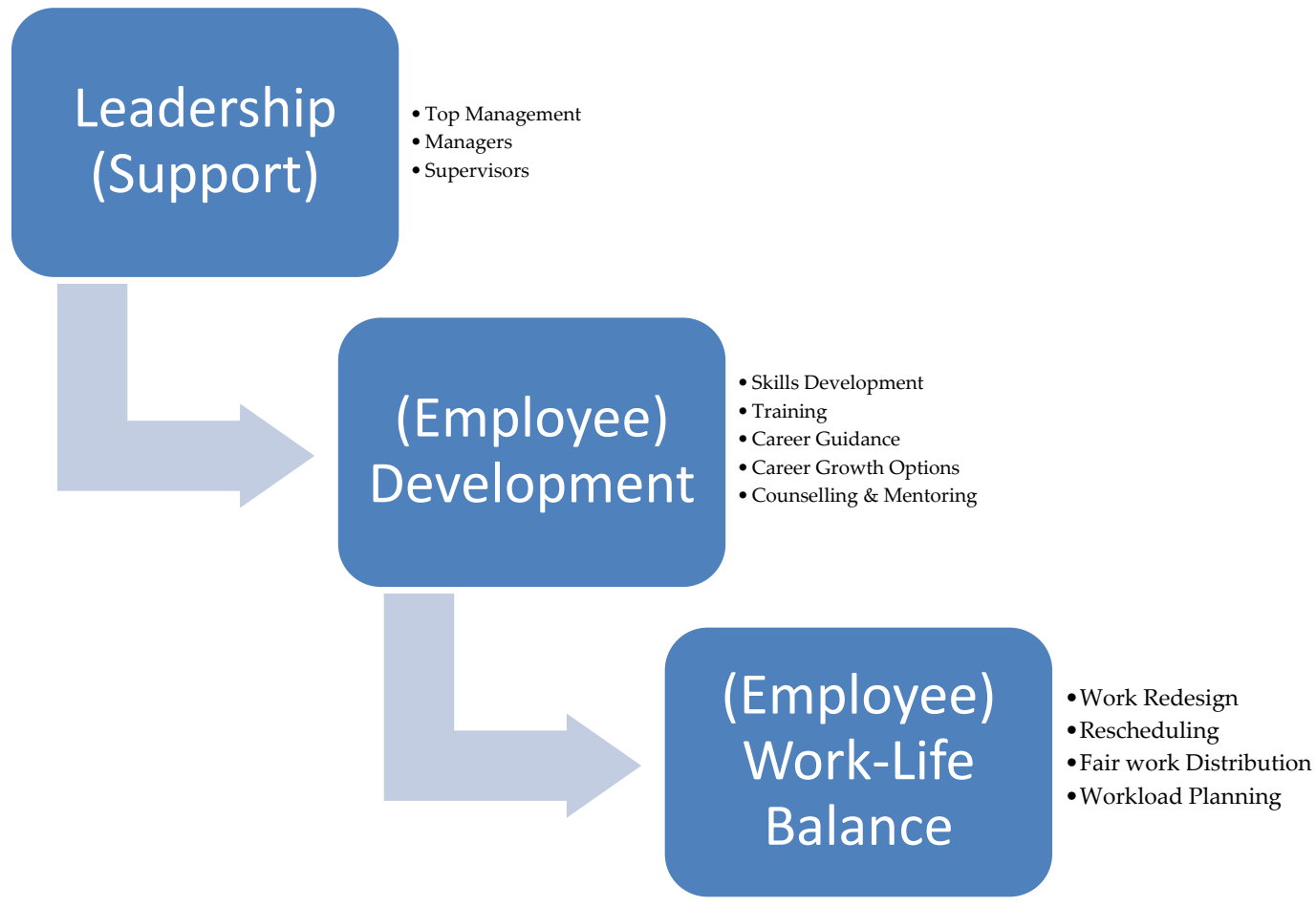

Figure 1. LDW Model

\subsubsection{Leadership}

Through the LDW model, we propose that leadership can play a critical role during the ongoing COVID-19 Pandemic to respond to the concern of meaningful work. Leadership in the shape of a manager, immediate supervisor, top management can all play a significant role in harnessing a sense of meaning and 
purpose with the work. A thorough review of the literature has outlined three prominent studies that support our assertion. To discuss a few, for example, a study by Arnold et al. (2007) suggests that transformational leadership infuses meaningful work, which further results in psychological well-being. Likewise, Tummers and Knies (2013) underlined that meaningful work could be predicted through leaders' help.

Thus, the LDW model proposes individuals with management and monitoring roles across organizations to help guide employees who appear to be lost during this chaotic period. Such individuals with leadership, management or supervisory roles may harness employees' psychological well-being through helping them connect with the diverse activities that they may be involved in due to limited staff; communicate them to see if they are facing any issues but have remained hesitant to discuss and deploy strategies to harmonize them to ensure they are doing well.

\subsubsection{Development}

The second component of the LDW model refers to Development, whereby it suggests that keeping in view the evolving job demands and requirements, organizations should strive to develop employees while using the available resources and facilities. This would help equip employees to respond to connect with the work, respond to challenges, and troubleshoot problems thus giving a sense of understanding and reasoning in performing a specific task. Some precious pieces of evidence hint at support for our assertion in this regard (e.g., Ahmed et al., 2018; Ayers et al., 2008).

Herein, the LDW model suggests that organizations can focus on employees' developmental needs to help them experience meaningfulness in their work. This can be done in many ways, for instance, through offering on-the-job training; through offering a developmental plan to progress over the next few years, counseling and mentoring options through experts and supervisors at work and so forth. The focus on the developmental aspect can help employees make a clearer sense of what they are doing, gain skills to perform the job, make the most of the available resources inside an organization through guidance, support, and mentoring from the experts and people in supervisory positions, thus enhancing the meaningfulness of the work.

\subsubsection{Work-Life-Balance}

Last but not least, the $\mathrm{W}$ in the LDW model denotes to work-life-balance. With mounting work pressure and multiple roles and responsibilities handled by every employee at work, their work-life balance has affected the most. Scholars have associated work-life balance with meaningful work (Munn, 2011), signaling that the absence of work-life-balance affects the sense, purpose, value, and significance of the work hence, resulting in doubts for the organizations. LDW model, therefore, recommends organizations to redesign work systems, roles, and allocation of responsibilities to ensure that it does not create disbalance employees' work-life nexus. This is critically essential to help employees maintain a sense of understanding, connectivity, and purpose with the organization, and above all, see themselves of value on a higher note.

Employees are missing the most in the shape of work-life balance due to the ongoing cOVID-19 pandemic and restructuring of work roles and responsibilities could potentially help organizations bring improvement in this regard without any additional resources and investments. This, for example, may include rescheduling of shifts, rotating work hours (Nelson \& Tarpey, 2010) to adjust and equally distribute among all employees, etcetera. 


\section{Conclusion}

In conclusion, we have worked to offer a scholarly evidence-supported model for COVID hit businesses to manage the issue of meaningful work. The LDW model offered in the present work forwards core areas of focus that could be conveniently considered without any need for investment or further resource allocation. In simple, LDW is asserted to be an effective and efficient model to help businesses bring back the lost sense of purpose, connectivity, value, and contribution in the employees so that they could give the best for the organizations in the shape of higher levels of engagement, commitment, and well-being.

\section{References}

Ahmed, U., Awang, Z. B., Hoque, A. S. M. M., Siddiqui, B. A., Dahri, A. S., \& Muda, H. (2018). The Mediating Role of Meaningful Work between Career Growth Opportunities and Work Engagement. International Journal of Academic Research in Business and Social Sciences, 8(11).

Ahmed, U., Majid, A. H. A., \& Zin, M. M. (2016). Moderation of meaningful work on the relationship of supervisor support and coworker support with work engagement. The Journal of Business, Economics, and Environmental Studies (JBEES), 6(3), 15-20.

Ahmed, U., Majid, A., Al-Aali, L., \& Mozammel, S. (2019). Can meaningful work really moderate the relationship between supervisor support, coworker support and work Engagement?. Management Science Letters, 9(2), 229-242.

Allan, B. A., Batz-Barbarich, C., Sterling, H. M., \& Tay, L. (2019). Outcomes of meaningful work: A metaanalysis. Journal of Management Studies, 56(3), 500-528.

Arnold, K. A., Turner, N., Barling, J., Kelloway, E. K., \& McKee, M. C. (2007). Transformational leadership and psychological well-being: the mediating role of meaningful work. Journal of Occupational Health Psychology, 12(3), 193.

Ayers, D. F., Miller-Dyce, C., \& Carlone, D. (2008). Security, dignity, caring relationships, and meaningful work: Needs motivating participation in a job-training program. Community College Review, 35(4), 257-276.

Darwish, S., Ahmed, U., \& Pahi, M. H. (2020). Innovative work behavior during COVID-19 for medical representative in the pharmaceutical industry: Test of a moderation model in bahrain. International Journal of Pharmaceutical Research, 12(4), 1927-1934.

Fairlie, P. (2011). Meaningful work, employee engagement, and other key employee outcomes: Implications for human resource development. Advances in Developing Human Resources, 13(4), 508-525.

Geldenhuys, M., Laba, K., \& Venter, C. M. (2014). Meaningful work, work engagement and organisational commitment. SA Journal of Industrial Psychology, 40(1), 01-10.

Hackman, J. R., \& Oldham, G. R. (1976). Motivation through the design of work: Test of a theory. Organizational Behavior and Human Performance, 16(2), 250-279

Hoole, C., \& Bonnema, J. (2015). Work engagement and meaningful work across generational cohorts. SA Journal of Human Resource Management, 13(1), 1-11.

Loffredo, L., Pacella, F., Pacella, E., Tiscione, G., Oliva, A., \& Violi, F. (2020). Conjunctivitis and COVID-19: a metaanalysis. Journal of Medical Virology.

Lysova, E. I., Allan, B. A., Dik, B. J., Duffy, R. D., \& Steger, M. F. (2019). Fostering meaningful work in organizations: A multi-level review and integration. Journal of Vocational Behavior, 110, 374-389.

Mo, Y., Deng, L., Zhang, L., Lang, Q., Liao, C., Wang, N., ... \& Huang, H. (2020). Work stress among Chinese nurses to support Wuhan in fighting against COVID-19 epidemic. Journal of Nursing Management.

Munn, S. L. (2013). Unveiling the work-life system: the influence of work-life balance on meaningful work. Advances in Developing Human Resources, 15(4), 401-417.

Nelson, M. F., \& Tarpey, R. J. (2010). Work scheduling satisfaction and work life balance for nurses: the perception of organizational justice. Academy of Health Care Management Journal, 6(1).

Rosso, B. D., Dekas, K. H., \& Wrzesniewski, A. (2010). On the meaning of work: A theoretical integration and review. Research in Organizational Behavior, 30, 91-127.

Schaufeli, W. B., Salanova, M., González-Romá, V., \& Bakker, A. B. (2002). The measurement of engagement and burnout: A two sample confirmatory factor analytic approach. Journal of Happiness studies, 3(1), 71-92. 
Smith, G. D., Ng, F., \& Li, W. H. C. (2020). COVID-19: Emerging compassion, courage and resilience in the face of misinformation and adversity. Journal of Clinical Nursing, 29(9-10), 1425.

Steger, M. F., Dik, B. J., \& Duffy, R. D. (2012). Measuring meaningful work: The work and meaning inventory (WAMI). Journal of career Assessment, 20(3), 322-337.

Tummers, L. G., \& Knies, E. (2013). Leadership and meaningful work in the public sector. Public Administration Review, 73(6), 859-868.

(C) 2020 by the author(s). Published by Annals of Contemporary Developments in Management \& HR (ACDMHR), under the terms and conditions of the Creative Commons Attribution (CC BY) license which can be accessed at http://creativecommons.org/licenses/by/4.0. 